\title{
Letter
}

\section{Effects of Light Wavelength and Intensity on the Expression of Photoresponse Genes in Oyster Mushroom Mycelia}

\author{
Yoko NAKANO*, Hiroshi FUJII ${ }^{* ; * *}$, and Masanobu KOJIMA ${ }^{*, * *, \#}$ \\ *Interdisciplinary Graduate School of Science and Technology, Shinshu University \\ * Department of Bioscience and Biotechnology, Shinshu University
}

Received June 21, 2010, Accepted August 31, 2010

\begin{abstract}
When oyster mushroom mycelia photoresponse genes responded to blue light, there was an inherent induction period, which lasted until the light stimulation caused up- and downregulation of the genes. The expression levels of the genes were highly dependent on the intensity of blue $(470 \mathrm{~nm})$ and green light $(525 \mathrm{~nm})$, while far-red $(735 \mathrm{~nm})$ and red light $(660 \mathrm{~nm})$ did not affect the expression level regardless of the intensity. In addition, when the mycelia were stimulated for $36 \mathrm{~h}$ using blue light at $105 \mu \mathrm{mol} \mathrm{m} \mathrm{m}^{-2}$ of photon flux density and then kept in the dark for $4 \mathrm{~d}$, the expression levels of a few downregulated genes became ca. 2.2 to 3 times greater than before irradiation. These findings have the potential to lead to the development of new phototechnology and techniques in which light-emitting diodes are used in the cultivation of edible mushrooms.
\end{abstract}

KEYWORDS: blue-light stimulation, effect of light wavelength and intensity, photoresponse genes, analysis of expression level, oyster mushroom mycelia

\section{Introduction}

Mushrooms are one of the most common agricultural products not only in Japan but also in many other countries. Among the commonly cultivated varieties, the yields of white mushroom (Agaricus bisporus (J. Lange) Imbach) and oyster mushroom (Pleurotus ostreatus) are the highest and second highest in the world, respectively ${ }^{1)}$. There have been several studies concerning the effects of light stimulation on the growth of mushroom mycelia and the formation and growth of fruit body primordia ${ }^{2)-5}$. However, many of the photoresponse phenomena in mushrooms remain unexplained and there has been particular interest in action mechanism governing response to light stimulation ${ }^{23)}$. The development of phototechnology in the cultivation of edible mushrooms has the potential to both reduce lighting costs and improve yields. Recently, we registered with the DNA Data Bank of Japan (DDBJ) our findings that 15 upregulated (UR1-15: Accession no. AB551953-551967 and $A B 551981-551986)^{6}$ ) and 13 downregulated genes (DR1-13: Accession no. AB551968-551980 and AB551987551989)6) which responded to blue-light stimulation had been identified using a random amplified polymorphic DNA differential display (RAPD DD) method ${ }^{7}$ and the characteristics of light-emitting diodes (LEDs). In this paper, we report that the expression levels of upregulated genes UR 1-4 depended on light wavelength and intensity, and also that for downregulated genes DR2 and 13, but not for DR1 and 3, expression was suppressed completely by blue-light stimulation, after which the expression levels for DR2 and 13 increased in the dark to become, respectively, ca. 2.2 times and ca. 3 times greater than before light stimulation. It should be noted that these findings have the potential to lead to improvements in the use of light in mushroom cultivation.

\section{Experimental}

\subsection{Media and strain}

A modified MA medium consisted of $10 \mathrm{~g}$ of malt extract, $10 \mathrm{~g}$ of $\mathrm{D}(+)$-glucose, $4 \mathrm{~g}$ of yeast extract, and $25 \mathrm{~g}$ of agar in 1 liter distilled water. A GPY medium consisted of $50 \mathrm{~g}$ of $\mathrm{D}(+)$-glucose, $2.5 \mathrm{~g}$ of polypeptone, $1.0 \mathrm{~g}$ of $\mathrm{KH}_{2} \mathrm{PO}_{4}, 0.5 \mathrm{~g}$ of $\mathrm{MgSO}_{4} 7 \mathrm{H}_{2} \mathrm{O}, 0.5 \mathrm{~g}$ of $\mathrm{CaCl}_{2} 2 \mathrm{H}_{2} \mathrm{O}, 10 \mathrm{mg}$ of $\mathrm{FeCl}_{2} 6 \mathrm{H}_{2} \mathrm{O}$, $7.2 \mathrm{mg}$ of $\mathrm{MnCl}_{2} 4 \mathrm{H}_{2} \mathrm{O}, 4.0 \mathrm{mg}$ of $\mathrm{ZnCl}_{2}, 1.0 \mathrm{mg}$ of $\mathrm{CuSO}_{4}$ $5 \mathrm{H}_{2} \mathrm{O}, 2.5 \mathrm{~g}$ of yeast extract, and $25 \mathrm{~g}$ of agar in 1 liter distilled water. The initial $\mathrm{pH}$ was adjusted to 5.5. The media were autoclaved at $121{ }^{\circ} \mathrm{C}$ for $20 \mathrm{~min}$ before use. The oyster mushroom KH-3 dikaryotic strain was first incubated at $20^{\circ} \mathrm{C}$ in the dark on the MA medium in a Pyrex Petri dish (diameter, $9 \mathrm{~cm}$ ) using an ELUX-1096 LED lighting unit for plant cultivation research (CCS). The fungal thread was grown concentrically to form a mycelial colony ca. $70 \mathrm{~mm}$ in diameter in the dark. From the periphery of the mycelial colony, a colony $6 \mathrm{~mm}$ in diameter was cut out and inoculated at the center of the GPY medium in a Petri dish. In experiments on the effect 
of light wavelength on mycelial growth, the colonies were irradiated immediately after inoculation. In gene expression analysis, colonies ca. $65 \mathrm{~mm}$ in diameter grown on the GPY media at $20^{\circ} \mathrm{C}$ in the dark were used.

\subsection{Dependence of mycelial growth on light wavelength}

Light intensity was set using photon flux density (PFD) measurements and an LI-250 Light Meter (LI-COR Bioscience) fitted with a light sensor: blue (peak emission wavelength or $\mathrm{PEW}, 470 \mathrm{~nm}$; spectrum radiation bandwidth or SRB, $30 \mathrm{~nm}$ ), green (PEW, $525 \mathrm{~nm}$; SRB, 40 $\mathrm{nm}$ ) and red light (PEW, $660 \mathrm{~nm}$; SRB, $20 \mathrm{~nm}$ ) were detected by an LI-190 quantum sensor (LI-COR Bioscience) and farred light (PEW, $735 \mathrm{~nm}$; SRB, $30 \mathrm{~nm}$ ) was detected by a 660/730nm SKR110 sensor (PP Systems International). Oyster mushroom mycelia were irradiated for $15 \mathrm{~d}$ using visible light at $95 \mu \mathrm{mol} \mathrm{m}^{-2} \mathrm{~s}^{-1}$ of PFD. The maximum and minimum diameters of 3 mycelial colonies were measured every day and the mean values were calculated. Change in growth ( $\Delta$ Growth) of the mycelial colonies was estimated as the difference between the mean value and the original colony size $(6$ $\mathrm{mm}$ ) before irradiation. The upper limit of total growth measurable was ca. $80 \mathrm{~mm}$ because of the size of the Petri dishes used.

\subsection{Analysis of the expression levels of UR1-4 under different light wavelengths and intensities}

Relative gene expression levels under different light wavelengths and intensities were determined by real-time PCR analysis. The forward and reverse primers of UR1-4 were designed using Primer Express 3.0 (Applied Biosystems) for TaqMan Primers and an MGB Probe. The accession numbers and primer sets of these genes are shown in Table 1, together with those of DR1-3 and 13.

Mycelial colonies were irradiated for $24 \mathrm{~h}$ using blue and green LEDs at 25, 50, 100 and $200 \mu \mathrm{mol} \mathrm{m}^{-2} \mathrm{~s}^{-1}$ of PFD, and also using red and farred LEDs at 100 and $200 \mu \mathrm{mol} \mathrm{m} \mathrm{m}^{-2} \mathrm{~s}^{-1}$ of PFD. Total RNAs were extracted from the frozen colonies in liquid nitrogen with an RNeasy Plant Mini Kit (Qiagen). Contaminating genomic DNA was removed using an RNase-Free DNase Set (Qiagen). First-strand cDNAs were synthesized from total RNAs with a High Capacity cDNA Reverse Transcription Kit (Applied Biosystems).

Relative gene expression levels of UR1-4 were determined in $\mathrm{SYBR}^{\circledast}$ Green Fast mode with a StepOne ${ }^{\mathrm{TM}}$ Real-time PCR System (Applied Biosystems). All reactions were run in triplicate. A non-template control for the primer set was included in each run, and 18S rRNA was used as an internal control. All procedures were carried out following the manufacturers' instructions.

\subsection{Time course of relative gene expression levels}

For DR1-3 and 13 mycelial colonies were irradiated for

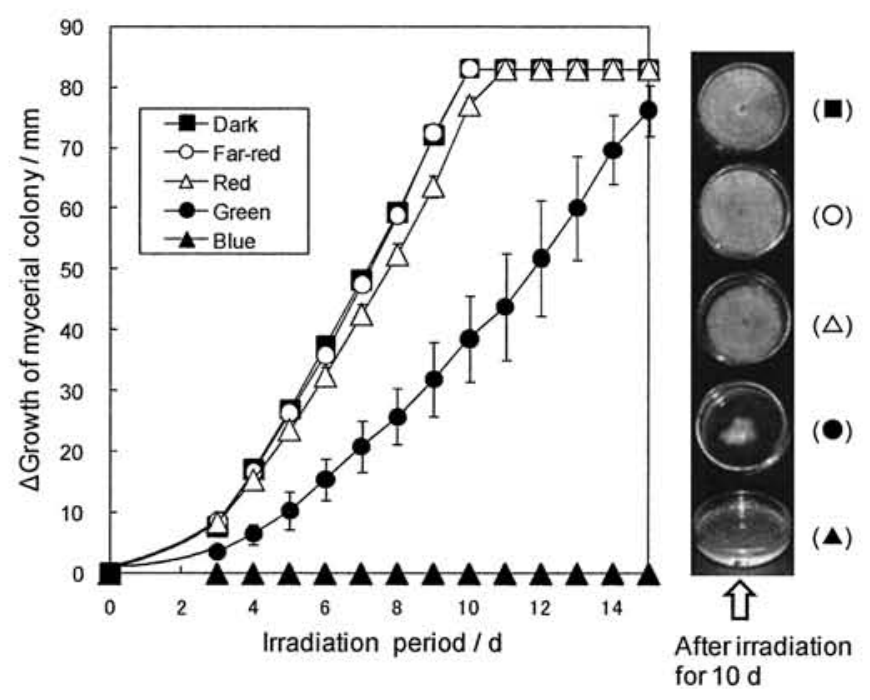

Figure 1 Suppression effect of light wavelength on the growth of oyster mushroom mycelia. The maximum and minimum diameters of 3 mycelial colonies were measured every day and the mean values were calculated. The markers show the cultivation conditions: in the dark ( $\mathbf{\square})$ and under far-red$(\circ)$, red- $(\Delta)$, green- $(\bullet)$, and blue-light irradiation $(\boldsymbol{\Delta})$. The error bars indicate the mean value \pm SD.

$36 \mathrm{~h}$ using blue LEDs at $105 \mu \mathrm{mol} \mathrm{m} \mathrm{m}^{-2} \mathrm{~s}^{-1}$ of PFD, and then kept in the dark for $4 \mathrm{~d}$. The time courses of the relative gene expression levels were determined as described above.

\section{Results and Discussion}

\subsection{Effect of light wavelength on the mycelial growth}

Although the mycelia were stimulated by red and farred light at $95 \mu \mathrm{mol} \mathrm{m}{ }^{-2} \mathrm{~s}^{-1}$ of PFD, as seen in Fig. 1, there was no significant difference in growth between the irradiated and non-irradiated mycelia. Even though the light intensity was increased up to $210 \mu \mathrm{mol} \mathrm{m} \mathrm{m}^{-2} \mathrm{~s}^{-1}$ of PFD, the light wavelength had no observable effect on mycelial growth. Contrastingly, blue- and green-light stimulation of the mycelia at $95 \mu \mathrm{mol} \mathrm{m} \mathrm{m}^{-2} \mathrm{~s}^{-1}$ of PFD caused delay in growth (see Figure 1). In particular, blue-light stimulation completely suppressed growth. Interestingly, after growth was suppressed for 3 weeks by blue-light stimulation and the mycelia then kept in the dark, they once again started to grow and form a colony. These results seem to indicate that blue light does not cause gene mutation or damage.

\subsection{Effect of light wavelength and intensity on the expression levels of UR1-4}

As shown in Figure 2, the expression levels of upregulated genes UR1-4 determined by real-time PCR analysis were entirely unaffected by red- and farred-light stimulation at both 100 and $200 \mu \mathrm{mol} \mathrm{m} \mathrm{m}^{-2} \mathrm{~s}^{-1}$ of PFD, compared to levels in the dark. In contrast, blue- and 
Table 1 Primer Sets for UR1-4 and DR1-3 and 13 Used in Real-Time PCR Analysis

\begin{tabular}{|c|c|c|c|}
\hline Gene & Accession no. & Forward primer & Reverse primer \\
\hline UR1 & $\begin{array}{l}\text { AB551953 } \\
\text { AB551981 }\end{array}$ & 5'-TCACCCCCAAGCTCCAATC-3' & 5'-CAATGGTTCATGGGCTACATAGTT-3' \\
\hline UR2 & $\begin{array}{l}\text { AB551954 } \\
\text { AB551982 }\end{array}$ & 5'-CGAATCCTCGGCATGCA-3' & 5'GGTGCGTCCGAAGCATCT-3' \\
\hline UR3 & $\begin{array}{l}\text { AB551955 } \\
\text { AB551983 }\end{array}$ & 5'-CCGACAAGAAGCGACAACGT-3' & 5'GGTGTCGGTGCCAATAACG-3' \\
\hline UR4 & $\begin{array}{l}\text { AB551956 } \\
\text { AB551984 }\end{array}$ & 5'-GACGTCGGATCGCTCGTTAT-3' & 5'-GCGCAGCTGATGACCTTCAT-3' \\
\hline DR1 & $\begin{array}{l}\text { AB551968 } \\
\text { AB551987 }\end{array}$ & 5'-TGCGGATGTTGTCCTACCAA-3' & 5'-TTGTACGTTGTGCCGCTTTG-3' \\
\hline DR2 & $\begin{array}{l}\text { AB551969 } \\
\text { AB551988 }\end{array}$ & 5'-GGTCTACTCCACCACTAGCCAACT-3' & 5'-TCACGTCCGCCCTCTGATAG-3' \\
\hline DR3 & $\begin{array}{l}\text { AB551970 } \\
\text { AB551989 }\end{array}$ & 5'-GCTGACGGCTCAACAAACG-3' & 5'-CCGATCTTCTCCAGCGATTG-3' \\
\hline DR13 & AB551980 & 5'AGTGACCGCTCAGCTGAACA-3' & 5'CCAGGCGTTCTGAATCGATT-3' \\
\hline
\end{tabular}

green-light stimulation caused an increase in the expression levels, depending on the light intensity. For example, on blue-light stimulation at $50-200 \mu \mathrm{mol} \mathrm{m} \mathrm{m}^{-2} \mathrm{~s}^{-1}$ of PFD the expression levels of UR1 and 3 increased with increase in PFD value. The levels at $100 \mu \mathrm{mol} \mathrm{m} \mathrm{m}^{-2} \mathrm{~s}^{-1}$ of PFD for UR1 and 3 were, respectively, ca. 20 and ca. 7 times greater than levels in the dark (Fig. 2a and c). For UR2 and 4, the expression levels became maxima at 100 $\mu \mathrm{mol} \mathrm{m} \mathrm{m}^{-2} \mathrm{~s}^{-1}$ of PFD (Fig. $2 \mathrm{~b}$ and d). Therefore, it is likely that $100 \mu \mathrm{mol} \mathrm{m} \mathrm{m}^{-2} \mathrm{~s}^{-1}$ of PFD is the optimum light intensity at which blue light simultaneously causes significant increase in the expression levels of UR1-4.

It is also interesting to note that green-light stimulation of UR3 at $100 \mu \mathrm{mol} \mathrm{m} \mathrm{m}^{-2} \mathrm{~s}^{-1}$ of PFD gave a higher expression level than blue-light stimulation. Because the green-light photoreceptors have been found in bacteria and fungi,,${ }^{8-10)}$ this result suggests that green-light photoreceptors and photoresponse genes might be contained in oyster mushroom mycelia. Further study will be necessary to understand this photoresponse behavior in UR3.

\subsection{Time Course of the expression levels of DR1-3 and 13} kept in the dark after blue-light stimulation

It is known that fruiting body development and the yield of fruiting bodies can be increased by the use of electric stimulation ${ }^{1112)}$. Reasoning by analogy, we might expect suitable blue-light stimulation followed by a period in the dark to cause an increase in the expression levels of some downregulated genes. We have confirmed that this assumption holds true for the genes DR2 and 13 but not for DR1 and 3, as seen in Figure 3. In this experiment, the mycelial colonies were irradiated by blue light at $105 \mu \mathrm{mol}$ $\mathrm{m}^{-2} \mathrm{~s}^{-1}$ of PFD for $36 \mathrm{~h}$, and then kept in the dark for $4 \mathrm{~d}$.

The expression levels of DR1-3 and 13 were measured by real-time PCR analysis at several intervals. For DR1, 2, and 13, the expression levels started to decrease after irradiation within $1 \mathrm{~h}$ and were almost completely suppressed after $36 \mathrm{~h}$. However, the expression levels of these genes recovered when the mycelial colonies were kept in the dark after irradiation, and in the case of DR2 and 13 after $4 \mathrm{~d}$ increased to levels which were, respectively, ca. 2.2 times and ca. 3 times greater than those before blue-light stimulation (Figure $3 \mathrm{~b}$ and d). For Shiitake mushroom (Lentinula edodes), it has been found that when the mycelial pellets formed on the surface of a culture solution were irradiated using fluorescent bulbs covered with blue colored sheets, the formation of the fruit body primordium and the morphogenesis and yield of the fruit body were closely dependent on the length of the period in the dark after irradiation ${ }^{45}$ ). It would be interesting if upregulated genes like UR1-4 and downregulated genes like DR2 and 13 were responsible for the morphogenesis and yield of oyster mushroom.

\section{Concluding remark}

We have demonstrated for the first time that by adjusting light wavelength and intensity together with irradiation time the expression levels of the photoresponse genes UR14 and DR1-3 and 13 in oyster mushroom mycelia can be upand downregulated. Although the functions of these genes have not been clearly understood at this stage, our findings suggest that the growth stage from mycelia pellets to fruit 

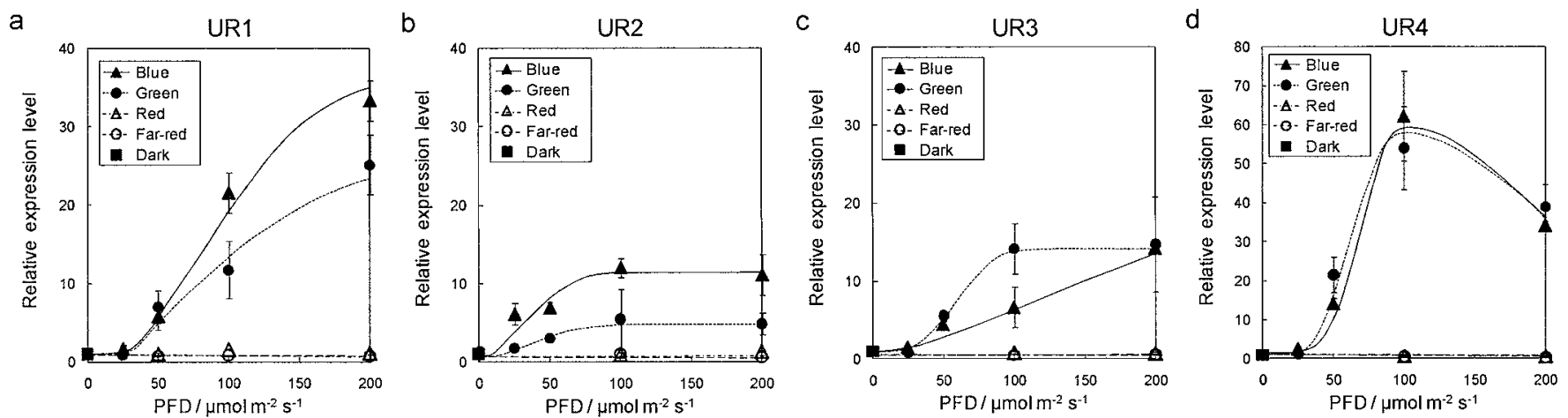

Figure 2 Relative gene expression levels of UR1-4 upregulated by different light wavelengths and intensities: in the dark ( $\mathbf{(})$ and under farred- $(\circ)$, red- $(\Delta)$, green- $(\bullet)$, and blue-light irradiation $(\Delta)$. The expression levels were measured in duplicate $($ error bar $=S D)$.
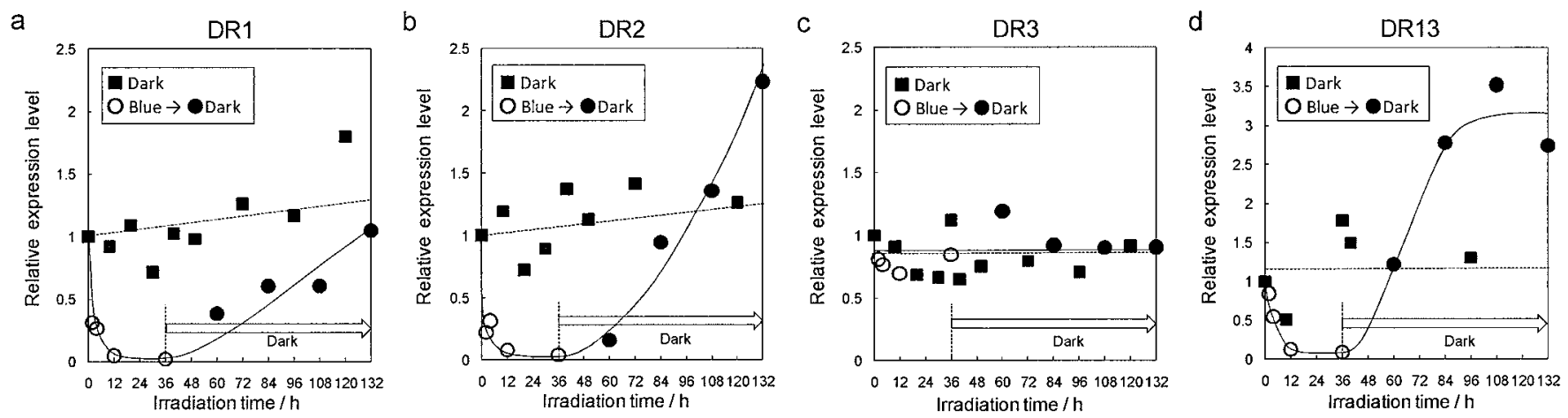

Figure 3 Time course of relative gene expression levels for DR1-3 and 13 in the dark after blue-light iradiation: in the dark ( $\mathbf{m}$ ), under bluelight irradiation (o), and in the dark after blue-light irradiation for $36 \mathrm{~h}(\bullet)$.

body primordia and also from the primordial to fruit bodies might be accelerated by blue-light stimulation. Further studies to develop phototechnology to cultivate edible mushrooms are in progress.

\section{Acknowledgments}

We thank Professor M. Fukuda of Shinshu University for helpful technical advice and information, and Murakami Farm Co., Ltd., for donations in support of this work.

\section{References}

(1) Sánchez, C.: Cultivation of Pleurotus ostreatus and other edible mushrooms, Appl. Microbiol. Biotechnol., 85, pp.1321-1337 (2010).

(2) Richartz, G. and Maclellan, A.J.: Action spectra for hyphal aggregation, the first stage of fruiting, in the basidiomycete Pleurotus ostreatus, Photochem. Photobiol., 45, pp.815-820 (1987).

(3) Arjona, D., Aragón, C., Aguilera, J.A., Ramírez, L. and Pisabarro, A.G.: Reproducible and controllable light induction of in vitro fruiting of the white-rot basidiomycete Pleurotus ostreatus, Mycol. Res., 113, pp.552-558 (2009).

(4) Mohamed, A. B. B., Meguro, S. and Kawachi, S.: The effects of light on primordia and fruit body formation of Lentinus edodes in a liquid medium, Mokuzai Gakkaishi, 38, pp.600-604 (1992).

(5) Mohamed, A. B. B., Meguro, S. and Kawachi, S.: The effects of light on primordia and fruit body formation of Lentinus edodes in a liquid medium II, Mokuzai Gakkaishi, 38, pp.876-879 (1992).

(6) DNA Data Bank of Japan (DDBJ): http://www.ddbj.nig.ac.jp/index-j.html.

(7) Kim, Y. J., Kwak, C. I., Gu, Y.Y., Hwang, I. T. and Chun, J. Y: Annealing control primer system for identification of differentially expressed genes on agarose gels, BioTechniques, 36, pp.424-434 (2004).

(8) Yoshihara, S., Shimada, T., Matsuoka, D., Zikihara, K., Kohchi, T. and Tokutomi, S.: Reconstitution of blue-green reversible photoconversion of a cyanobacterial photoreceptor, PixJ1, in phycocyanobilin-producing Escherichia coli, Biochem., 45, pp.3775-3784 (2006).

(9) Bieszke, J. A., Li, L. and Borkovich, K. A.: The fungal opsin gene nop-1 is negatively-regulated by a 
component of the blue light sensing pathway and influences conidiation-specific gene expression in Neurospora crassa, Curr. Genet., 52, pp.149-157 (2007).

(10) Suzuki, D., Furutani, Y., Inoue, K., Kikukawa, T., Sakai, M., Fuji, M., Kandori, H., Homma, M. and Sudo, Y.: Effects of chloride ion binding on the photochemical properties of Salinibacter sensory rhodopsin I, J. Mol. Biol., 392, pp.48-62 (2009).

(11) Takaki, K., Yamazaki, N., Mukaigawa, S., Fujiwara, T., Kofujita, H., Takahasi, K., Narimatsu, M. and Nagane, K.: Improvement of edible mushroom yield by electric stimulations, J. Plasma Fusion Res. SERIES, 8, pp.556-559 (2009).

(12) Ohga, S.: Application of electric stimulation to mushroom production system, BIOINDUSTRY, 2312 , pp.33-42 (2006).

\# To whom correspondence should be addressed. 8304 Minamiminowa, Kamiina, Nagano 399-4598, Japan Fax:+81-265-77-1627, E-mail:mkojima@shinshu-u.ac.jp 